\title{
Combined non-isotopic in situ hybridisation and indirect immunohistochemical analysis of hormone production in the rat pituitary gland
}

\author{
N Sanno, A Matsuno, J Itoh, K Kakimoto, A Teramoto, R Y Osamura
}

\begin{abstract}
An understanding of the intracellular relation between hormonal expression (storage) and gene expression (production) is essential for elucidating the functional status of the individual cells in endocrine tissue such as the pituitary gland. To this end, mRNA expression was visualised by using a combined in situ hybridisation and immunohistochemistry method in routinely processed, formalin fixed, paraffin wax embedded rat pituitaries. mRNA was detected by non-isotopic in situ hybridisation (alkaline phosphatase antialkaline phosphatase method, with nitroblue tetrazolium and 5-bromo-4chloro-3-indolylphosphate as substrates). Sections were then stained by using the immunoperoxidase method to demonstrate pituitary hormone expression. The specificity of the combined staining method was confirmed by staining adjacent sections separately. The antigenicity of rat growth hormone and prolactin was adequately preserved following hybridisation. In conclusion, this method is specific, easy to use and permits the determination of the functional status of individual cells.
\end{abstract}

(f Clin Pathol: Mol Pathol 1996;49:M57-M60)

Keywords: in situ hybridisation, mRNA, immunohistochemistry, pituitary, endocrine tissue.

In situ hybridisation (ISH) is being increasingly used to detect mRNA in tissue sections. Many investigators have studied anterior pituitary hormone specific gene expression using radioisotopic in situ hybridisation. ${ }^{1-5}$ The non-isotopic ISH method, however, has been reported as having several advantages over its radioisotopic counterpart. ${ }^{26}$ The simultaneous demonstration of mRNA expression and the presence of its product would provide more precise information about the functional status of a cell, especially in endocrine tissue such as in the pituitary. Analysis of both the hormone and the specific mRNA encoding the hormone will increase the chances of characterising individual cells which store only small amounts of hormone but contain abundant message or, conversely, store abundant hormone but contain only a small amount of message. In pituitary adenomas, such a discrepancy between gene expression and the product of gene expression has been suggested. ${ }^{178}$ In the rat pituitary, prolactin mRNA has been detected in cells from fetal day 18 onwards. However, using immunohistochemistry (IHC) prolactin could not be detected until 10 days after birth. ${ }^{9}$ This discrepancy may also be present in normal adult pituitaries, but has not been demonstrated conclusively as yet. We postulated that a method combining ISH and IHC would give more precise information about the relation between a mRNA and its product at the cellular level.

\section{Methods}

Seven week old male Wistar-Imamichi rats (200-250 g) were studied. The anterior pituitary glands were fixed in $10 \%$ buffered formalin overnight and embedded in paraffin wax. Sections, $4 \mu \mathrm{m}$ thick, were then cut, mounted on 3-aminopropyltriethoxy silane coated glass slides and subjected to ISH and staining by the indirect immunoperoxidase method.

IN SITU HYBRIDISATION

Oligonucleotide probes for rat growth hormone and prolactin were synthesised in a DNA synthesiser (Applied Biosystems, model 392) and had the following sequences: $5^{\prime}-\mathrm{d}$ (CTG TTG CGA TAC GAG GCG CGG) and 5'-d (GGC TTC CTG CTT CTC TTC AGG), respectively. ${ }^{1}$ The specificities of these probes have been confirmed previously. ${ }^{1-7}$

The oligonucleotides were $3^{\prime}$ end labelled with biotin using the Enzo (Farmingdale, New York, USA) terminal labelling kit. The details of the in situ hybridisation method have been reported previously. ${ }^{7}$ Briefly, paraffin wax sections, $4 \mu \mathrm{m}$ thick, were deparaffinised, rinsed in $2 \times$ SSC (standard sodium citrate) and treated with $0 \cdot 2 \mathrm{~N} \mathrm{HCl}$ at room temperature for 20 minutes. Various concentrations of proteinase $\mathrm{K}(5 \mu \mathrm{g} / \mathrm{ml}, 10 \mu \mathrm{g} / \mathrm{ml}$ or $20 \mu \mathrm{g} / \mathrm{ml})$ were then applied at $37^{\circ} \mathrm{C}$ for 30 minutes. The slides were then treated for 10 minutes with $0 \cdot 25 \%$ 
(v/v) acetic anhydride in $0 \cdot 1 \mathrm{M}$ triethanolamine at room temperature, rinsed in $2 \times \mathrm{SSC}$ and prehybridised at $37^{\circ} \mathrm{C}$ for 30 minutes in a prehybridisation solution containing $10 \%$ (w/ v) dextran sulphate, $3 \times$ SSC, $1 \times$ Denhardt's solution $\quad(0.02 \% \quad(w / v) \quad$ Ficoll $/ 0.02 \% \quad(w / v)$ bovine serum albumin $/ 0.02 \%(\mathrm{w} / \mathrm{v})$ polyvinylpyrrolidone), $100 \mathrm{mg} / \mathrm{ml}$ salmon sperm DNA, $125 \mathrm{mg} / \mathrm{ml}$ yeast tRNA, $10 \mathrm{mg} / \mathrm{ml} \mathrm{poly-}$ adenylic-cytidylic acid, $1 \mathrm{mg} / \mathrm{ml}$ sodium pyro-

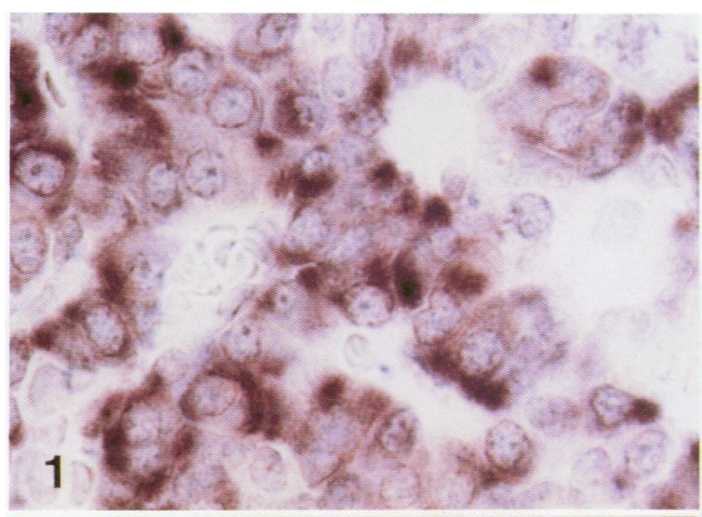

\section{2}
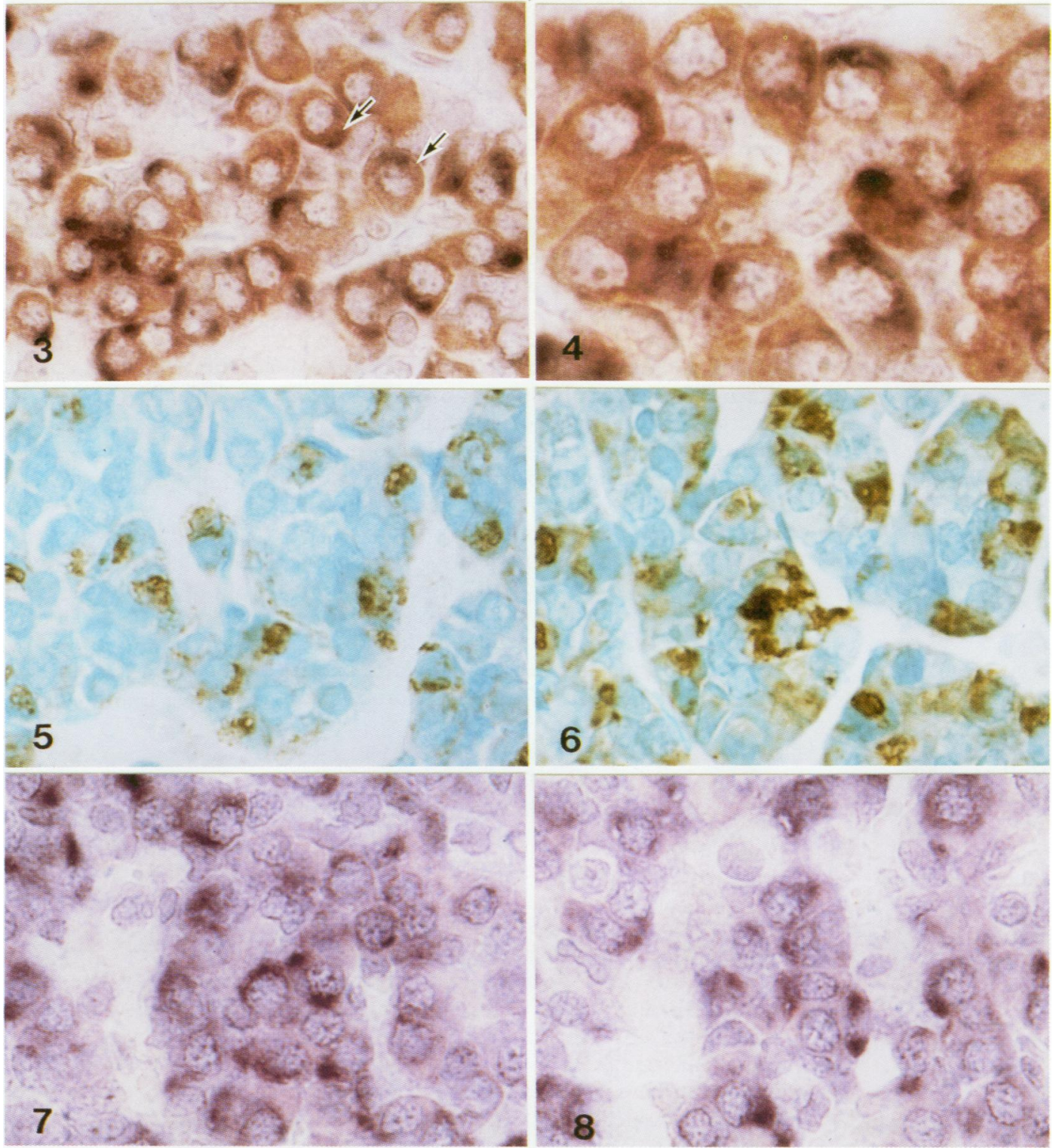

Panel 1, ISH incorporating the antisense probe for prolactin $m R N A$, with blue staining indicating a positive signal; panel 2, ISH incorporating the sense probe for prolactin $m R N A$ on an adjacent section. The hybridisation signal is absent. Panels $3(\times 600)$ and $4(\times 850)$, combined ISH and IHC for prolactin mRNA and prolactin protein. The hybridisation signal for mRNA (blue) can be easily distinguished from the positive signal on IHC (brown) (arrows). The mRNA and its protein product are not always co-localised. Panel 5, as for panel 3 but lacking staining with NBTBCIP. Immunoreactivity far from being reduced, is enhanced by the hybridisation procedure. Panel 6, standard IHC for prolactin protein on the adjacent section without ISH. Panel 7, ISH for prolactin mRNA and IHC without the primary antibody directed against prolactin. Panel 8, ISH for prolactin $m R N A$ and IHC without the secondary antibody $(\times 600)$ 
phosphate, $\mathrm{pH} 7 \cdot 4$, and $50 \%(\mathrm{v} / \mathrm{v})$ formamide. The biotinylated probes were diluted with this solution and the subsequent hybridisation was carried out at $37^{\circ} \mathrm{C}$ overnight. The concentration of the probes was $0 \cdot 1 \mathrm{ng} / \mathrm{ml}$. After hybridisation, the slides were washed with $2 \times$ SSC and then the hybridisation signal was visualised using nitroblue tetrazolium (NBT) and 5-bromo-4-chloro-3-indolylphosphate (BCIP), according to the manufacturer's instructions (Dako, Carpinteria, California, USA). Negative control experiments were carried out with sense probes and in the absence of probes.

\section{IMMUNOHISTOCHEMISTRY}

The indirect immunoperoxidase method was used to characterise the hormonal content of individual cells. The following primary antisera were applied: anti-rat growth hormone rabbit serum (diluted 1 in 200; UCB Bioproducts, Braine-L'Alleud, Belgium) and anti-rat prolactin rabbit serum (diluted 1 in 200; National Institute of Diabetes and Digestive and Kidney diseases, Bethesda, Maryland, USA). Horseradish peroxidase conjugated anti-rabbit IgG (goat) (diluted 1 in 50; Amersham, Little Chalfont, UK) was used as the secondary antibody. Positive immunoreactivity was visualised as brown staining on incubation with $3,3^{\prime}$ diaminobenzidine (DAB).

\section{COMBINED IN SITU HYBRIDISATION AND} IMMUNOHISTOCHEMISTRY

After ISH, the slides were washed in $2 \times$ SSC and were then stained by the indirect immunoperoxidase method. A positive reaction on ISH was visualised as blue and on IHC as brown.

\section{EXPERIMENTAL DESIGN TO CONFIRM THE}

SPECIFICITIES OF IHC AND ISH

The following experiments were carried out on serial paraffin wax sections, including various negative controls, to confirm the specificity of the procedure:

- ISH using antisense probe for growth hormone (or prolactin) mRNA;

- ISH using sense probe for growth hormone (or prolactin) mRNA;

- combined ISH-IHC for growth hormone (or prolactin) mRNA and growth hormone (or prolactin) protein;

- combined ISH-IHC for growth hormone (or prolactin) mRNA and growth hormone (or prolactin) protein without visualisation by NBT-BCIP;

- standard IHC for growth hormone (or prolactin) protein;

- combined ISH-IHC for growth hormone (or prolactin) mRNA and growth hormone (or prolactin) protein in the absence of the primary antibody for growth hormone (or prolactin);

- combined ISH-IHC for growth hormone (or prolactin) mRNA and growth hormone (or prolactin) protein in the absence of the secondary antibody for growth hormone (or prolactin).

\section{Results}

ISH for growth hormone mRNA and prolactin mRNA resulted in a strong hybridisation signal in the rat pituitaries. A positive signal was detected in many anterior pituitary cells, and very strong signals were observed in the lateral wings (figure, panel 1). The control ISH experiments utilising the sense probes for growth hormone and prolactin mRNA were negative (figure, panel 2).

Using the combined ISH and IHC method, there was a good contrast between the blue staining of a positive hybridisation signal and brown staining on IHC. Co-localisation of ISH signals for mRNA and immunoreactivities for growth hormone or prolactin protein could be seen clearly (figure, panel 3). The extent of the hybridisation signal varied from cell to cell and the signal intensities for the mRNAs were not always comparable with the immunoreactivities for their products. That is to say, some cells expressed the mRNA and not its protein product. Others had very weak hybridisation signals but had stronger immunoreactivity for the protein.

Growth hormone and prolactin protein immunoreactivities were not affected by the hybridisation procedure and were comparable with those sections in which IHC was applied alone (figure, panels 4 and 5). In some cases the immunoreactivities were enhanced following in situ hybridisation. Immunoreactivity was not influenced by the concentration of proteinase $\mathrm{K}$, although the hybridisation signal was better at the higher concentration whereas tissue preservation was better in the lower concentration (data not shown). The controls lacking the primary or secondary antibodies were negative (figure, panels 6 and 7).

\section{Discussion}

We have previously reported procedures for detecting mRNA using biotinylated oligonucleotide probes in the human pituitary. ${ }^{78}$ In the present study we have extended these studies to the simultaneous demonstration of the hormonal mRNAs and their corresponding protein products in routinely processed sections. Although mRNAs and their products can be visualised in separate serial sections, one would expect that combining ISH and IHC on the same section would facilitate comparative evaluation of functional information at the cellular level.

We were particularly interested in how much antigenicity would be preserved after ISH. The concentration of proteinase $\mathrm{K}$ was regarded as one of the most important factors which could influence hybridisation signal intensity, as well as preservation of antigenicity. From our previous experiments, ${ }^{7} 10 \mu \mathrm{g} / \mathrm{ml}$ proteinase $\mathrm{K}$ was the most appropriate concentration for preserving cell morphology and also the hybridisation signal for mRNA in paraffin wax sections. In the present study, we applied 5, 10 and $20 \mu \mathrm{g} / \mathrm{ml}$ proteinase $\mathrm{K}$ in order to investigate whether antigen retrieval would be diminished. Our results indicate the application 
of $20 \mu \mathrm{g} / \mathrm{ml}$ proteinase $\mathrm{K}$ did not diminish subsequent detection of protein by IHC; moreover, antigen retrieval was sometimes better than with IHC alone. Battifora and Kopinski ${ }^{10}$ found that protease digestion greatly enhanced antigen retrieval. A similar mechanism may have been in operation in the present study.

Müllink et $a l^{11}$ have suggested that when the combination of ISH and IHC is applied to the same section, ISH should be performed after immunostaining because the digestion steps may hinder antigen retrieval. However, when IHC was carried out before ISH, staining with DAB often masked staining with NBT-BCIP, making evaluation much more difficult. In the present study, we have confirmed that carrying out ISH before IHC does not reduce antigen retrieval. This method is specific, easy to use and permits the determination of the functional status of individual cells.

1 Lloyd RV. Analysis of human pituitary tumors by in situ hybridization. Pathol Res Pract 1988;183:558-60.

2 Hankin RC, Lloyd RV. Detection of messenger RNA in routinely processed tissue sections with biotinylated oligonucleotide probes. Am $\mathcal{f}$ Clin Pathol 1989;92:166-70.

3 Lloyd RV, Cano M, Chandler WF, Barkan AL, Horvath E Kovacs K. Human growth hormone and prolactin se- creting pituitary adenomas analyzed by in situ hybridization. Am f Pathol 1989;134:605-13.

4 Kilar F, Muhr C, Funa K. In situ hybridization histochemistry of mRNAs for hormones and chromogranins in normal pituitary tissue and pituitary adenoma. Acta Endocrinol (Copenh) 1991;125:628-36.

5 Li J, Stefaneanu L, Kovacs K, Horvath E, Smyth HS. Growth hormone $(\mathrm{GH})$ and prolactin (PRL) gene expression and immunoreactivity in GH and PRL-producing human pituitary adenomas. Virchows Arch A Pathol Anat Histopathol 1993;422:193-201.

$6 \mathrm{McNicol}$ AM, Farquharson MA, Walker E. Non-isotopic in situ hybridization with digoxigenin and alkaline phosin situ hybridization with digoxigenin and alkaline phosphatase labelled oligodeoxynucleotide probes. Ap-
plications in pituitary gland. Pathol Res Pract 1991;187: plications

7 Matsuno A, Teramoto A, Takekoshi S, Sanno N, Osamura RY, Kirino T. Expression of plurihormonal mRNAs in somatotroph adenomas detected using a non-isotopic in situ hybridization method-comparison with lactotroph adenomas. Hum Pathol 1995;26:272-9.

8 Sanno N, Teramoto A, Matsuno A, Takekoshi S, Osamura RY. GH and PRL gene expression by nonradioisotopic in situ hybridization in TSH-secreting pituitary adenomas. f Clin Endocrinol Metab 1995;80:2518-22.

9 Hooghe-Peters EL, Belayew A, Herregodts P, Velkeniers B, Smets C, Martial JA, et al. Discrepancy between prolactin (PRL) messenger ribonucleic acid and PRL content in (PRL) messenger ribonucleic acid and PRL content in
rat fetal pituitary cells: possible role of dopamine. Mol rat fetal pituitary cells: po
Endocrinol 1988;2:1163-8.

10 Battifora $H$, Kopinski $M$. The influence of protease digestion and duration of fixation on the immunostaining of keratins. A comparison of formalin and ethanol fixation. 7 Histochem Cytochem 1986;34:1095-100

11 Müllink H, Wakboomers JMM, Tadema TM, Jansen DJ, Meijer JLM. Combined immuno- and non-radioactive hybridocytochemistry on cells and tissue sections: influence of fixation, enzyme pre-treatment, and choice of chromogen on detection of antigen and DNA sequences. f Histochem Cytochem 1989;37:603-9. 